\title{
First report of aster yellows phytoplasma infection of marigold plants in Hungary
}

\author{
Orsolya Viczián $^{1} \cdot$ Emese Kiss $^{1} \cdot$ Mária Szabó $^{2} \cdot$ Emese Mergenthaler $^{1}$
}

Published online: 28 March 2018

(C) Società Italiana di Patologia Vegetale (S.I.Pa.V.) 2018

French marigold (Tagetes patula L.) is a widely cultivated ornamental plant worldwide. In 2012 serious "phytoplasmalike" infections were found on marigold in Hungary. Leaves became colored and deformed, interveinal shortening and virescence were also observed. The disease is seriously threatening marigold plantations and breeding projects. DNA was extracted from petioles and phloem tissues of healthy and infected plants using a CTAB method (Ahrens and Seemüller, 1992). PCR assay was carried out employing the primer pair R16F2n/R16R2 (Lee et al. 1994). The purified PCR amplicons of 16S rDNA were sequenced using the $\mathrm{fU} 5 / \mathrm{rU} 3$ primers. Alignment of sequences was performed with Clustal W (Thompson et al. 1994). Phylogenetic comparisons were performed with MEGA4. The sequences were compared to each other and to other reference sequences in the NCBI database. Phylogenetic analyses revealed a main clade of the Hungarian and other sequences belonging to the $16 \mathrm{Sr}$ I group.

The 16Sr DNA fragment sequence of the $800 \mathrm{bp}$ amplicon of the isolate and that of a ' $\mathrm{Ca}$. Phytoplasma asteris' reference isolate (HM467127) were used for the in silico digestion for further identification. Both sequences were digested in silico with 11 restriction endonucleases. The restriction products were separated on a virtual gel generated by the pDRAW32 software. Based on all analyzed RFLP patterns our isolate proved to be part of the 16Sr I group and shows similarity with a ' $\mathrm{Ca}$. P. asteris' isolate.

To our knowledge this is the first molecular identification of a natural 'Candidatus Phytoplasma asteris' infection in Hungarian marigold plantations.

\section{References}

Ahrens U, Seemüller E (1992) Detection of DNA of plant pathogenic mycoplasmalike organisms by a polymerase chain reaction that amplifies a sequence of the $16 \mathrm{~S}$ rRNA gene. Phytopathology 82:828-832

Lee IM, Gundersen DE, Hammond RW, Davis RE (1994) Use of 274 mycoplasmalike organism (MLO) group-specific oligonucleotide primers for nested-275 PCR assays to detect mixed-MLO infections in a single host plant. Phytopathology 84276 (6):559-566

Thompson JD, Higgins DG, Gibson TJ (1994) CLUSTAL W: improving the sensitivity of progressive multiple sequence alignment through sequence weighting, position-specific gap penalties and weight matrix choice. Nucleic Acids Res 22:4673-4680

Orsolya Viczián

viczian.orsolya@agrar.mta.hu

1 Hungarian Academy of Sciences, Centre for Agricultural Research, Plant Protection Institute, 1525, Herman Ottó St. 15,

Budapest, Hungary

2 National Agricultural Research and Innovation Centre (NARIC) Fruitculture Research Institute, Park st. 2., Budapest 1223, Hungary 